\title{
PENGARUH BERBAGAI KONSENTRASI PUPUK ORGANIK CAIR KOTORAN KELELAWAR TERHADAP PRODUKSI DAN MUTU FISIOLOGIS BENIH KANGKUNG
}

\section{THE EFFECT OF VARIOUS CONCENTRATIONS OF BAT LIQUID ORGANIC FERTILIZER (LOF) ON PRODUCTION AND PHYSIOLOGICAL QUALITY OF KALE SEEDS}

\author{
Ali Hasan ${ }^{1}$, Yosefina Lewar ${ }^{2}$ Laurensius Lehar ${ }^{3 *}$ dan Rosita Kewa Duan ${ }^{4}$ \\ 1,2,3 Dosen Politeknik Pertanian Negeri Kupang \\ Jurusan Tanaman Pangan dan Hortikultura, Program Studi Teknologi Industri Hortikultura \\ ${ }^{4}$ Mahasiswa Program Studi Teknologi Industri Hortikultura. \\ e-mail: *laurensiusl@yahoo.co.id
}

\begin{abstract}
ABSTRAK
Penelitian bertujuan untuk mengetahui pengaruh berbagai konsentrasi pupuk organik cair kotoran kelelawar terhadap produksi dan mutu fisiologis benih kangkung. Penelitian faktor tunggal yaitu konsentrasi pemberian pupuk organik cair kotoran kelelawar yang terdiri dari 6 taraf yaitu 0, 50, 100, 150, 200, dan $250 \mathrm{ml}$ POC/liter. Penelitian disusun dalam rancangan acak kelompok $(R A K)$ dan diulang 4 kali. Pengamatan dikakukan terhadap kandungan hara POC kotoran kelelawar dan tanah awal, kandungan hara tanah sesudah perlakuan, jumlah bunga dan buah per tanaman, jumlah biji bernas per tanaman, bobot kering biji per petak, daya berkecambah serta $T_{50}$. Hasil penelitian menunjukkan konsentrasi POC kotoran kelelawar berpengaruh terhadap variable produksi (jumlah bunga per tanaman, jumlah buah per tanaman, jumlah biji bernas per tanaman dan bobot kering biji per petak). Konsentrasi POC kotoran kekelawar juga berpengaruh terhadap variable mutu fisiologis benih kangkung (daya berkecambah dan $T_{50}$ ). Konsentrasi $150 \mathrm{ml}$ POC/liter memberikan hasil terbaik, ditunjukkan oleh tolok ukur jumlah bunga per tanaman ( 58,4 kuntum), Jumlah buah per tanaman (54,6), jumlah biji bernas per tanaman (33,4 buah), bobot kering biji per petak (106 g), tetapi dan daya berkecambah tertinggi pada konsentrasi $200 \mathrm{ml}$ POC/liter (85,5\%).
\end{abstract}

Kata kunci: benih kangkung, pupuk organik cair kotoran kelelawar, perkecambahan

\section{ABSTRACT}

The study aimed to determine the effect of various concentrations of bat manure liquid organic fertilizer on the production and physiological quality of kale seeds. Single factor research was the concentration of bat organic waste liquid fertilizer which consisted of 6 levels, namely 0, 50, 100, 150, 200, and $250 \mathrm{ml}$ LOF / liter. The study was arranged in a randomized block design (RBD) and repeated 4 times. Observations were made on the nutrient content of LOF bat and initial soil, soil nutrient content after treatment, number of flowers and fruit per plant, number of seeds per plant, dry weight of seeds per plot, germination, and T50. The results showed LOF concentration of bat droppings effect on production variables (number of flowers per plant, number of fruits per plant, number of seeds per plant and seed dry weight per plot). LOF concentrations of bat manure also affect the physiological quality variables of spinach seeds (germination power and T50). The concentration of $150 \mathrm{ml}$ LOF / liter gave the best 
results, indicated by the benchmark of the number of flowers per plant (58.4 buds), number of fruits per plant (54.6), number of seeds per plant (33.4 fruits), dry weight of seeds per plot (106 $\mathrm{g})$, but the highest germination was at a concentration of $200 \mathrm{ml} \mathrm{LOF} /$ liter (85.5\%).

Keyword: kale seeds, bat manure liquid organic fertilizer, germination

\section{PENDAHULUAN}

Kangkung termasuk jenis sayuran yang populer di kalangan masyarakat Indonesia khususnya masyarakat menengah ke bawah, karena selain harganya relatif murah juga memiliki kandungan gizi yang baik. Kebutuhan kangkung meningkat sejalan dengan meningkatnya kesadaran masyarakat akan pentingnya gizi. Meningkatnya kesadaran masyarakat akan keamanan pangan, maka dewasa ini kecenderungan permintaan sayuran organik termasuk kangkung juga meningkat.

Pertanian organik merupakan sistem manajemen produksi pertanian yang holistik (keseluruhan) dan terpadu, dengan cara mengoptimalkan kesehatan dan produktivitas agroekosistem secara alami, sehingga mampu menghasilkan pangan dan serat yang cukup berkualitas serta berkelanjutan. Menurut Sutanto (2002), pengertian pertanian organik merupakan suatu sistem produksi pertanaman yang berasaskan daur ulang hara secara hayati. Daur ulang hara dapat melalui sarana limbah tanaman dan ternak serta limbah lainnya yang mampu memperbaiki kesuburan tanah. Dalam memperbaiki kesuburan tanah, dalam pertanian organik digunakan pupuk organik baik padat maupun cair (POC).

POC adalah jenis pupuk yang diekstrak dari berbagai unsur organik menjadi bentuk cair sehingga mudah diaplikasikan. Kelebihan pupuk organik cair adalah cepat mengatasi defisiensi hara, tidak bermasalah dalam pencucian hara dan mampu menyediakan hara secara cepat. Penggunaan POC memiliki beberapa keuntungan yakni aplikasinya lebih mudah jika dibandingkan dengan pupuk organik padat, unsur hara yang terdapat dalam POC lebih mudah diserap tanaman, mengandung mikroorganisme yang jarang terdapat dalam 128 | Jurnal Agriekstensia Vol. 17 No. 2 Desember 2018 pupuk organik padat dan pencampuran POC dengan organik padat dapat mengaktifkan unsur hara dalam pupuk organik padat tersebut (Djuarnani dan Susilo, 2006). Salah satu kotoran hewan yang digunakan untuk membuat pupuk organik cair adalah kotoran kelelawar. Di Nusa Tenggara Timur terutama di Timor Tengah Utara dan Timor Tengah Selatan cukup banyak terdapat kotoran kelelawar namun kotoran kelelawar oleh masyarakat sekitar belum dimanfaatkan secara optimal sebagai pupuk, padahal kotoran kelelawar mempunyai potensi sebagai pupuk karena kandungan haranya. Menurut Suwarno dan Idris (2007) kotoran kelelawar mengandung Nitrogen (N) 7-17\%, fosfor (P) 8-15\%, kalium (K) 1,5\%- 2,5\%. Unsur hara yang terkandung dalam kotoran kelelawar antara lain 9-13\% N, 5-12\% P, $1,5-2,5 \% \mathrm{~K}, 7,5-11 \% \mathrm{Ca}, 0,5-1 \mathrm{Mg}$, dan 23,5\% S (Agronomedia, 2010).

Beberapa hasil penelitian mengenai pupuk kotoran kelelawar pada sayuran memperlihatkan adanya pengaruh terhadap hasil tanaman. Hasil penelitian (Saverianus, 2015) tentang penggunaan pupuk organik cair kotoran kelelawar untuk mengurangi dosis pupuk anorganik pada tanaman mentimun menunjukkan bahwa konsentrasi POC kotoran kelelawar 125ml/1 air menghasilkan klorofil daun paling banyak yaitu 29,79 $\mathrm{mg} / \mathrm{ml}$, diikuti yang diberi pupuk onorganik sesuai dosis anjuran yaitu 29,37 $\mathrm{mg} / \mathrm{ml}$, serta kombinasi POC $100 \mathrm{ml} / \mathrm{l}$ air dan $1 / 8$ dosis pupuk anorganik yaitu 29,14mg/ml. Nugrahini (2013) pada penelitiaanya mengenai pemberian pupuk kotoran kelelawar pada selada menghasilkan berat segar paling tinggi. Penelitian Djafar dan Barus (2013) memperlihatkan pemberian pupuk guano dengan dosis pupuk 4,8g yang dikombinasi dengan urine kelinci konsentrasi 60 ml/1air 
meningkatkan secara nyata tingi dan jumlah daun tanaman sawi.

Prasyarat benih untuk pertanian organik adalah benih atau bahan perbanyakan lainnya diproduksi pada kondisi pertanian organik (EEC 2092/91). Didalam SNI 6729: 2013 disebutkan bahwa benih harus berasal dari tumbuhan yang ditumbuhkan secara organik paling sedikit satu generasi atau dua musim. Mutu benih sangat dipengaruhi oleh kesehatan tanaman induknya. Aplikasi POC kotoran kelelawar diduga meningkatkan ketersediaan phytin pada biji yang penting untuk proses perkecambahan benih.

\section{METODE PENELITIAN}

Kegiatan penelitian ini dilaksanakan di Kebun Praktek dan Laboratorium Program Studi Teknologi Industri Hortikultura dari Bulan Juni sampai September 2017. Rancangan percobaan yang digunakan dalam penelitian ini adalah Rancangan Acak Kelompok (RAK). Faktor yang dicobakan adalah konsentrasi POC kotoran kelelawar dengan enam taraf perlakuan yaitu: $0 \mathrm{ml} \mathrm{POC/liter} \mathrm{(kontrol} \mathrm{=}$ $\mathrm{P} 0), 50 \mathrm{ml} \mathrm{POC} /$ liter (P1), $100 \mathrm{ml} \mathrm{POC/} \mathrm{liter}$ )P2), $150 \mathrm{ml}$ POC guano/ liter (P3), $200 \mathrm{ml}$ $\mathrm{POC} /$ liter (P4) dan $250 \mathrm{ml} \mathrm{POC/} \mathrm{liter} \mathrm{(P5).}$ Percobaan diulang 4 kali sehingga terdapat 24 satuan percobaan. Ukuran petak tiap satuan percobaan adalah 2 x 1,2 meter. Benih ditanam dengan jarak tanam $20 \times 15$ $\mathrm{cm}$ sehingga terdapat 78 rumpun tanaman. Pada umur 4 MST batang tanaman dipangkas pada $8 \mathrm{~cm}$ di atas permukaan tanah. Tunas-tunas yang muncul dipelihara. Pada 3 minggu setelah pangkas, pemberian air dikurangi untuk merangsang pembungaan. Aplikasi POC dilakukan setiap minggu dengan dosis $250 \mathrm{ml} /$ tanaman Selanjutnya dilakukan pengamatan. Data yang diperoleh dianalisis menggunakan analisis ragam (Anova) untuk mengetahui pengaruh perlakuan. Perbedaan pengaruh perlakuan diuji dengan uji lanjut BNJ (Beda Nyata Jujur) 5\% untuk melihat perbedaan antarperlakuan. Pengamatan dilakukan 129 | Jurnal Agriekstensia Vol. 17 No. 2 Desember 2018 terhadap kandungan hara POC kotoran kelelawar dan tanah awal, kandungan hara tanah sesudah perlakuan, jumlah bunga dan buah per tanaman, jumlah biji bernas per tanaman dan bobot kering biji per petak, dan daya berkecambah serta $T_{50}$.

\section{HASIL DAN PEMBAHASAN}

\section{Kandungan Hara POC Kotoran Kelelawar, Tanah Awal dan Tanah Akhir}

Analisis POC kotoran kelelawar dan Tanah Awal meliputi N, P, K, dan Oorganik seperti tampak pada Tabel 1.

Tabel 1. Kandungan Hara POC Kotoran

Kelelawar dan Tanah Awal

\begin{tabular}{lcccc}
\hline $\begin{array}{c}\text { Kandungan } \\
\text { hara }\end{array}$ & \multicolumn{2}{c}{ POC Kelelawar } & \multicolumn{2}{c}{ Tanah Awal } \\
\hline & $\begin{array}{c}\text { Kadar } \\
\text { hara }\end{array}$ & Harkat & $\begin{array}{c}\text { Kadar } \\
\text { hara }\end{array}$ & Harkat \\
N $(\%)$ & 3,29 & $\begin{array}{c}\text { Sangat } \\
\text { tinggi }\end{array}$ & 0,28 & Sedang \\
P (ppm) & 3,01 & Tinggi & 25,79 & Tinggi \\
K $(\mathrm{me} / 100 \mathrm{~g})$ & 2,90 & $\begin{array}{c}\text { Sangat } \\
\text { rendah }\end{array}$ & 0,78 & Tinggi \\
C-organik $(\%)$ & 2,11 & Sedang & 2,14 & Sedang \\
\hline
\end{tabular}

Data analisis POC kotoran kelelawar menunjukkan bahwa kandungan hara $\mathrm{N}$ sebesar 3,29\% dan kandungan hara $\mathrm{K}$ sebesar 2,90 me/100g tergolong sangat tinggi, dibandingkan dengan kandungan hara $\mathrm{P}$ sebesar 3,01 ppm harkatnya tinggi dan kandungan hara C-organik sebesar 2,11\% tergolong sedang. Hal ini akan mempengaruhi kesuburan tanah dan pertumbuhan tanama.

Data analisis tanah sebelum perlakuan menunjukkan harkat kandungan kadar hara berbeda-beda. Kandungan hara N dan Corganik tergolong sedang, sedangkan kandungan hara $\mathrm{P}$ dan $\mathrm{K}$ tergolong tinggi. Dari hasil pengukuran menunjukkan kandungan hara berkisar sedang sampai tinggi. Hal ini disebabkan pemberian pupuk dasar berupa kotoran sapi. Ketersediaan hara dalam tanah perlu ditambahkan melalui pemupukan yang banyak mengandung unsur hara $\mathrm{P}$ agar produksi benih yang hasilkan lebih banyak. Salah satu pupuk yang banyak 
Pengaruh Berbagai Konsentrasi Pupuk Organik Cair Kotoran. .. (A. Hasan, Y. Lewar, L. Lehar dan Rosita K.D) mengandung unsur hara $\mathrm{P}$ adalah kotoran kelelawar

Analisis kandungan hara tanah setelah perlakuan bertujuan untuk mengetahui kadar hara yang yang diserap oleh tanaman selama masa tanam. Analisis kimia tanah setelah perlakuan adalah $\mathrm{N}, \mathrm{P}$, $\mathrm{K}$, dan C-organik dapat dilihat pada Tabel 2.

Tabel 2. Kandungan Hara Tanah Sesudah

\begin{tabular}{ccccc}
\multicolumn{5}{c}{ Perlakuan } \\
\hline Perlakuan & $\mathbf{N}(\%)$ & $\mathbf{P}(\mathbf{p p m})$ & $\begin{array}{c}\mathbf{K} \\
(\mathbf{m e} / \mathbf{1 0 0 g})\end{array}$ & $\begin{array}{c}\mathbf{C}- \\
\text { organik } \\
(\boldsymbol{\%})\end{array}$ \\
\hline P0 & $0,18 \mathrm{R}$ & $20,82 \mathrm{~S}$ & $0,55 \mathrm{~S}$ & $1,32 \mathrm{R}$ \\
P1 & $0,29 \mathrm{~S}$ & $25,91 \mathrm{~T}$ & $0,73 \mathrm{~T}$ & $1,34 \mathrm{R}$ \\
P2 & $0,30 \mathrm{~S}$ & $34,87 \mathrm{~T}$ & $0,83 \mathrm{~T}$ & $1,36 \mathrm{R}$ \\
P3 & $0,31 \mathrm{~S}$ & $35,01 \mathrm{ST}$ & $0,85 \mathrm{~T}$ & $1,36 \mathrm{R}$ \\
P4 & $0,32 \mathrm{~S}$ & $37,09 \mathrm{ST}$ & $0,86 \mathrm{~T}$ & $1,06 \mathrm{R}$ \\
P5 & $0,33 \mathrm{~S}$ & $36,98 \mathrm{ST}$ & $0,91 \mathrm{~T}$ & $1,06 \mathrm{R}$ \\
\hline
\end{tabular}

Keterangan huruf: $\mathrm{S}=$ sedang, $\mathrm{R}=$ rendah, $\mathrm{T}=$ tinggi, $\mathrm{ST}=$ sangat tinggi

Data analisis tanah sesudah perlakuan menunjukkan bahwa pada semua perlakuan kandungan hara naik terkecuali perlakuan kontrol atau tanpa POC. Hal ini dipengaruhi oleh pemupukan POC kotoran kelelawar. Konsentrasi POC kotoran kelelawar meningkatkan kandungan unsur hara dalam tanah dan memperbaiki kesuburan tanah.

\section{Jumlah Bunga dan Buah per Tanaman}

Konsentrasi POC kelelawar
berpengaruh nyata terhadap jumlah
bunga/tanaman kangkung darat . Rata- rata
jumlah bunga/tanaman kangkung darat pada
berbagai dosis POC kotoran kelelawar
tertera pada Tabel 3.

Tabel 3. Rata-rata jumlah bunga dan buah per tanaman kangkung darat pada berbagai konsentrasi POC kotoran kelelawar

\begin{tabular}{ccc}
\hline Konsentrasi POC & $\begin{array}{c}\text { Jumlah } \\
\text { Bunga }\end{array}$ & Jumlah Buah \\
\hline Kontrol (Tanpa POC) & 48,4 ab & $39,8 \mathbf{a}$ \\
$50 \mathrm{ml}$ & $46,5 \mathbf{a b}$ & $40,8 \mathbf{a}$ \\
$100 \mathrm{ml}$ & $42,6 \mathbf{a}$ & $42,0 \mathbf{a}$ \\
$150 \mathrm{ml}$ & $58,4 \mathbf{c}$ & $54,6 \mathbf{b}$ \\
$200 \mathrm{ml}$ & $51,1 \mathbf{b}$ & $49,2 \mathbf{b}$ \\
$250 \mathrm{ml}$ & $48,3 \mathbf{a b}$ & $45,3 \mathbf{a}$ \\
\hline BNJ 5\% & $\mathbf{7 , 0}$ & $\mathbf{6 , 1 9 3 9 6}$ \\
\hline
\end{tabular}

130 | Jurnal Agriekstensia Vol. 17 No. 2 Desember 2018

Konsentrasi POC kotoran kelelawar berpengaruh nyata terhadap jumlah bunga/tanaman kangkung darat. Konsentrasi $150 \mathrm{ml}$ POC /liter memberikan jumlah bunga tertinggi dan berbeda dengan perlakuan lain. Konsentrasi, 50, 100, 200, dan $250 \mathrm{ml} \mathrm{POC/liter} \mathrm{tidak} \mathrm{berbeda} \mathrm{dengan}$ kontrol. Inisiasi bunga ditentukan oleh keseimbangan $\mathrm{C}$ dan $\mathrm{N}$ dalam jaringan tanaman (Salisbury and Ross, 1995). Kandungan P dalam POC kotoran kelelawar yang tinggi memungkinkan pembentukan protein (senyawa kaya N) lebih tinggi. Diduga konsentrasi $150 \mathrm{ml}$ POC/liter memberikan keseimbangan $\mathrm{C}$ dan $\mathrm{N}$ yang optimal sehingga menghasilkan jumlah bunga tertinggi.

Poerwowidodo (2010) menyatakan bahwa tersedianya unsur hara dalam jumlah yang cukup dan seimbang dapat meningkatkan proses pertumbuhan tanaman seperti proses fotosintesis dan pemanjangan sel akan berlangsung cepat yang mengakibatkan beberapa organ pertumbuhan tanaman berkembang lebih cepat terutama pada fase generatif. Hara yang tersedia cukup dan berimbang akan berpengaruh terhadap pertumbuhan tanaman yang lebih baik, sebaliknya pertumbuhan tanaman terhambat sehingga mempengaruhi pembentukan fase generatif seperti pembentukan bunga dan Buah (Sitompul, 1995).

Jumlah buah per tanaman dipengaruhi oleh konsentrasi POC (Tabel 3). Konsentrasi POC 150 dan $200 \mathrm{ml}$ POC/liter memberikan jumlah buah tertinggi dan berbeda dari konsentrasi POC lainnya. Hal ini sejalan dengan variable jumlah bunga/tanaman yang tertinggi pada konsentrasi $150 \mathrm{ml} \mathrm{POC/liter,} \mathrm{tetapi} \mathrm{pada}$ variable jumlah buah/tanaman pada konsentrasi $200 \mathrm{ml} \mathrm{POC/liter} \mathrm{tidak} \mathrm{berbeda}$ dengan $150 \mathrm{ml}$ POC/liter.

Ketersediaan unsur-unsur hara lebih banyak diperoleh pada konsentrasi POC kotoran kelelawar yang lebih tinngi. Konsentrasinya POC kotoran kelelawar yang lebih tinggi juga memiliki komposisi hara lengkap dan seimbang yang dibutuhkan 
oleh tanaman. Menurut Sumarni (2005), komposisi hara seimbang yang dimaksud adalah kandungan unsur hara makro dan mikro yang dibutuhkan telah terkandung dalam larutan hara POC kotoran kelelawar. Pada konsentrasi $150 \mathrm{ml} \mathrm{POC/liter} \mathrm{telah}$ memenuhi kebutuhan tanaman sehingga mampu membentuk buah yang lebih banyak.

\section{Jumlah Biji Bernas per Tanaman dan Bobot Kering Biji per Petak}

Jumlah biji bernas per tanaman dan bobot kering biji per petak nyata dipengaruhi oleh konsentrasi POC (Tabel 4). Konsentrasi $150 \mathrm{ml}$ POC/liter memberikan jumlaj biji bernas per tanaman tertinggi, tetapi tidak berbeda dengan konsentrasi 200 dan $250 \mathrm{ml} \mathrm{POC/liter.} \mathrm{Konsentrasi} 50$ dan $100 \mathrm{ml} \mathrm{POC} /$ liter tidak berbeda dengan kontrol. Konsentrasi $150 \mathrm{ml}$ POC/liter juga memberikan hasil terbaik pada variable bobot kering biji per petak. Hal ini seseuai dengan pengaruh konsentrasi POC pada jumlah bunga dan buah yang memberikan hasil tertinggi juga pada konsentrasi $150 \mathrm{ml}$ POC/liter.

Tabel 4. Rata-rata Jumlah Biji Bernas per

Tanaman dan Bobot Kering Biji per Petak Tanaman Kangkung Darat pada Berbagai Konsentrasi POC Kotoran Kelelawar

\begin{tabular}{ccc}
\hline Konsentrasi POC & $\begin{array}{c}\text { Jumlah } \\
\text { Biji } \\
\text { bernas }\end{array}$ & $\begin{array}{c}\text { Bobot Biji } \\
\text { Kering per } \\
\text { Petak (g) }\end{array}$ \\
\hline Kontrol (Tanpa POC) & $23,3 \mathbf{a}$ & $92,525 \mathbf{~ a}$ \\
$50 \mathrm{ml}$ & 24,9 a & $100,05 \mathbf{a}$ \\
$100 \mathrm{ml}$ & $23,6 \mathbf{a}$ & $96,3 \mathbf{a}$ \\
$150 \mathrm{ml}$ & $33,4 \mathrm{~b}$ & $106 \mathbf{b}$ \\
$200 \mathrm{ml}$ & $30,6 \mathbf{b}$ & 99,825 a \\
$250 \mathrm{ml}$ & $29,9 \mathbf{b}$ & $96,825 \mathbf{a}$ \\
\hline BNJ 5\% & $\mathbf{4 , 2 5 4 0 8}$ & $\mathbf{1 0 , 2 4 2 8}$ \\
\hline
\end{tabular}

Keterangan : Angka- angka yang diikuti oleh huruf yang sama pada kolom yang sama menunjukkan tidak berbeda nyata pada uji BNJ $5 \%$

Konsentrasi POC yang sesuai kebutuhan tanaman akan meningkatkanbaik pertumbuhan vegetatif maupun generatif tanaman. Pertumbuhan generatif tanaman yaitu pembentukan bunga serta pembentukan dan pengisian biji tanaman membutuhkan 131 | Jurnal Agriekstensia Vol. 17 No. 2 Desember 2018 suplai $\mathrm{P}$ yang cukup. Ketersediaan $\mathrm{P}$ pada konsentrasi $150 \mathrm{ml}$ POC/liter telah memenuhi kebutuhan tanama untuk pembentukan dan pengisian biji. Amin (2007) dalam Amin (2009) melaporkan bahwa pemupukan $\mathrm{P}$ dapat menambah jumlah berat biji kedelai, demikian pula pertumbuhan dan hasil tanaman.

\section{Daya berkecambah dan $\mathbf{T}_{50}$}

Daya berkecambah dan $\mathrm{T}_{50}$ nyata dipengaruhi oleh konsentrasi POC kotoran kelelawar (Tabel 5). Daya berkecambah tertinggi $(85,5 \%)$ dicapai pada perlakuan konsentrasi $200 \mathrm{ml}$ POC/liter, pemberian POC pda konsentrasi lainnya tidak berbeda dengan kontrol. $\mathrm{T}_{50}$ merupakan tolok ukur kecepatan perkecambahan, yaitu waktu yang dibutuhkan untuk mencapai $50 \%$ perkecambahan. Tampak bahwa aplikasi POC pada semua dosis yang dicobakan nyata menurunkan nilai $\mathrm{T}_{50}$, Kecepatan perkecambahan mengindikasikan vigor benih, semakin rendah $\mathrm{T}_{50}$ menunjukkan benih lebih vigor. Diduga pemberian POC kotoran kelelwar yang kaya akan $P$ menyebabkan kandungan fitat pada biji yang cukup untuk mendukung metabolisme perkecambahan benih, sesuai Copeland and Mc. Donald (1995) yang menyatakan bahwa kandungan fitat dibutuhkan dalam proses perkecambahan karena mampu menyediakan unsur- unsur mikro dan P.

Tabel 5. Rata-rata Daya Berkecambah (DB) dan $\mathrm{T}_{50}$ Benih Tanaman Kangkung Darat pada Berbagai Konsentrasi POC

Kotoran Kelelawar

\begin{tabular}{ccc}
\hline Konsentrasi POC & DB (\%) & $\mathbf{T}_{\mathbf{5 0}}$ (hari) \\
\hline Kontrol (Tanpa POC) & $79,5 \mathbf{a}$ & $4,89 \mathbf{b}$ \\
$50 \mathrm{ml}$ & $84 \mathbf{a}$ & $4,33 \mathbf{a}$ \\
$100 \mathrm{ml}$ & $84,5 \mathbf{a}$ & $4,42 \mathbf{a}$ \\
$150 \mathrm{ml}$ & $85 \mathbf{a}$ & $4,59 \mathbf{a}$ \\
$200 \mathrm{ml}$ & $85,5 \mathbf{b}$ & $4,39 \mathbf{a}$ \\
$250 \mathrm{ml}$ & $74 \mathbf{a}$ & $4,85 \mathbf{a}$ \\
\hline BNJ 5\% & $\mathbf{1 1 , 4 3 6 6 9}$ & $\mathbf{0 , 5 4 4 7 2 1}$ \\
\hline
\end{tabular}

Keterangan: Angka- angka yang diikuti oleh huruf yang sama pada kolom yang sama menunjukkan tidak berbeda nyata pada uji BNJ $5 \%$ 


\section{KESIMPULAN}

Konsentrasi POC kotoran kelelawar berpengaruh terhadap variabel produksi (jumlah bunga per tanaman, jumlah buah per tanaman, jumlah biji bernas per tanaman dan bobot kering biji per petak. Konsentrasi POC kotoran kekelawar juga berpengaruh terhadap variabel mutu fisiologis benih kangkung ( daya berkecambah dan $\mathrm{T}_{50}$ ). Konsentrasi $150 \mathrm{ml}$ POC/liter memberikan hasil terbaik, ditunjukkan oleh tolok ukur jumlah bunga per tanaman ( 58,4 kuntum), Jumlah buah per tanaman $(54,6$ buah), jumlah biji bernas per tanaman ( 33,4 butir), bobot kering biji per petak $(106 \mathrm{~g})$, tetapi dan daya berkecambah tertinggi pada konsentrasi 200 $\mathrm{ml}$ POC/liter $(85,5 \%)$

\section{DAFTAR PUSTAKA}

Agromedia. 2010. Petunjuk Pemupukan Tanaman. Agromedia Pustaka. Jakarta.

Amin. 2007. Pengaruh Pemupaka P Pada Pertumbuhan Kedelai Dan Berat Biji. Bandung

Copelland, M, B. dan McDonald. 1995. Principles Of Seed Science and Teknologi. London: Collier Macmillan Publisher.

Djafar, T, A, A. Barus dan Syukri. 2013. Respon Pertumbuhan dan Produksi Sawi (brassica junceaL) Terhadap Pemberian Urine Kelinci dan Pupuk Guano. Jurnla Online Agroekoteknologi 1 (3).

Djuarnani dan Susilo. 2006. Pembuatan dan Manfaat Pupuk Organik Cair. Diakses 20 Novembar 2017.

Maria , G.M. 2009. Respon Produksi Tanaman Kangkung Darat Terhadap Variasi Waktu

132 | Jurnal Agriekstensia Vol. 17 No. 2 Desember 2018
Pemberian Pupuk Kotoran Ayam. Jurnal Ilmu Tanah. Jakarta

Nugrahini. 2013. Pengaruh Pemberian Pupuk Guano Pada Produksi Tanaman Selada. Bandung.

Poerwowidodo. 2010. Telaah Kesuburan Tanah. Angkasa. Bogor.

Salisbury, F.B., \& C.W. Ross. 1995. Fisiologi Tumbuhan (Terjemahan Lukman, D.R., dan Sumaryono). ITB, Bandung.

Santi. 2013. Pengaruh Pemberian Pupuk Kandang terhadap Pertumbuhan Kangkung Darat (Ipomoea Reptans Poir) pada Media Pasir Pantai. Banyuwangi. Jawa Timur. Jurnal Agroforestri.

Sitompul, S. 1995. Analisis Pertumbuhan Tanaman. Gadjah Mada University Press, Yogyakarta.

Sumarni. 2005. Budidaya Tanaman Cabai Merah. Balai Penelitian Tanaman Sayuran. Yogyakarta.

Sutanto, R. 2002. Pertanian Organik Menuju Pertanian Alternatif Berkelanjutan. Kanisius, Yogyakarta.

Widodo, 2008. Pupuk Organik dan Pupuk Hayati. Balai Besar Penelitian dan Pengembangan Sumberdaya Lahan Pertanian Jawa Barat. Bandung. 